Annals of Plant Sciences

\title{
Antimicrobial and in vitro cytotoxic studies of Acampe praemorsa and Aeridis odarata of Orchidaceae
}

Jhansi K., Khasim S.M.

Department of Botany and Microbiology, Acharya Nagarjuna University, Nagarjunanagar, Guntur 522510, India.

Received: 1/16/2018; Accepted: 1/29/2018

\begin{abstract}
This paper aims at studying antimicrobial efficacy and in vitro cytoxic activity of epiphytic orchids namely Acampe praemorsa, Aeridis odorata distributed in Eastern Ghats of Visakhapatnam district. Plants were collected, identified following literature, shade dried and Methanol, ethyl acetate extracts were prepared for the systematic investigation of antimicrobial activity of plant extracts. Antibacterial activity against three gram positive bacteria Bacillus megaterium, Lactobacillus acidophillus and Enterococcus faecalis, three gram negative bacteria Proteus vulgaris, Klebsiella pneumoniae and Escherichia coli was done using Agar well diffusion method, antifungal activity was carried against Candida albicans, Aspergillus flavus by Cpzapak dox agar media, MIC by broth dilution method, zones of inhibition were recorded. Ethyl acetate extracts showed maximum antimicrobial activity against all bacteria and fungi, Aeridis odarata ethyl acetate extract showed highest zone of inhibition $17 \mathrm{~mm}$ against Lactobacillus acidophilus in bacteria, Ethyl acetate extract of Acampe praemorsa showed highest zone of inhibition $17 \mathrm{~mm}$ against Candida albicans in fungi, the leaf extracts were tested for its inhibitory effect on HeLa and MCF-7 cell lines were evaluated by the MTT assay and methanolic extract of Aeridis odarata has significant cytotoxicity effect on MCF-7 cell line in concentration range between 5 to $100 \mu \mathrm{g} / \mathrm{ml}$, with IC $50(\mu \mathrm{g} / \mathrm{ml})$ value is 26.2. These plants have good antimicrobial activity, further investigation on the phytochemistry of bioactive compounds of these plants would result in discovery of new drugs and further pharmacological investigation of anti-cancer activity of Aeridis odarata should be done.
\end{abstract}

Keywords: Antimicrobial efficacy, Broth dilution, Czapek dox, MIC, Zone of inhibition.

\section{Introduction}

Orchidaceae is one of the largest family with more than 30,000 species, 750 genera in the world. Orchids are nature's most extravagant group of flowering plants distributed throughout the world from tropics to Alpine (White \& Sharma, 2000). They are most diverse of the flowering plant families with over 184 genera, 1331 species specific to India (Kumar et al., 1994). The domestic, cultural, medicinal, basic needs of human have been fulfilling by plants since time immemorial. In many countries like China, in some parts of Europe and America, Australia and Africa, Orchids have been used as traditional drugs for a very long time (Dash et al., 2008). The earliest Middle East report of plant remedies is in a 4000- year old Sumerian clay tablet which included some orchids (Kong et al., 2003). They are also one of the ingredients in ancient Indian systems of medicine called Ayurveda (Bijaya pant, 2013). These plants first received recognition in herbal writings of China and Japan, 3000 to 40000 years ago and they were the first to describe orchids for medicinal use (Bulpitt, 2005). Acampe praemorsa, Aeridis odarata are epiphytes, collected in Eastern Ghats near Paderu.

The ethnobotanical value of these plants were studied and people have been using for various problems. To the South in Andhra Pradesh on the Eastern ghats, the Koya tribe uses the pulverized

\section{${ }^{*}$ Corresponding Author:}

Jhansi K.,

Department of Botany and Microbiology,

Acharya Nagarjuna University,

Nagarjunanagar, Guntur 522510, India.

E-mail: jhansi.katta@rediffmail.com plant Acampe praemorsa, mixed with egg white and calcium to produce a paste for application on fractured limbs to promote healing (Reddy et al., 2005). Ten drops of warm butter prepared from cow milk taken on leaf of this plant and bandaged to the legs of kids to cure tetanus (Behera et al., 2013). It's leaf juice is applied over the nipple for stomach ache and it is also used for ear ache, controlling body temperature (Shanavaskan et al., 2012). The tribal in Araku valley showed that leaf paste along with a piece of garlic for 7 days taken to get relief from chest pain and stomach disorder caused by hyper acidity (Padal et al., 2013). Healers use Aeridis odarata based herbal formulations combination with different herbs for skin diseases (Pankaj Oudhia, 1990-2012). The leaf juice of this plant is used to control mild tuberculosis (Dash $e t$ al., 2008), leaf paste of this plant was used to treat cuts, wounds (Bijaya Pant, 2013) to cure boils in ear and nose (Hossain, 2009). The whole plant and leaves are used to treat pneumonia, dyspepsia, epilepsy, paralysis, inflammation, waist ache and fractures (Akhtar et al., 2017). Leaves of Acampe praemorsa, Luisia zeylanica and aerial roots of Cymbidium aloifolium were used to fix human bone fractures (Behera et al., 2013). These ethnobotanical uses shows antimicrobial property of plants. Many biologists, biochemists, pharmacologists are doing experimental works on orchids all over the world. A 
wide range of chemical compounds have been isolated from various parts of orchids. They are important in compounds from reducing fevers, increasing WBC count, curing eye infection, treating fatigue and head ache, and most importantly functioning as an anticancer agent (Bulpitt, 2005), Indian Vanda orchid express anti proliferative effects against various types of cancer (Ho et al., 2003), hence an attempt has been made to evaluate antimicrobial activity of these two epiphytes were conducted in various extracts and in vitro cytotoxicity of the plants against HeLa and MCF-7 cell lines was done.

\section{Materials and Methods}

Leaves were collected near Paderu, Visakhapatnam, Andhra Pradesh, they are washed and dried in shade, the dried material was made into a coarse powder by means of electrical grinder. The dried powdered leaf material was extracted in ethyl acetate and methanol solvents, the resulted extracts were filtered and then concentrated.

\section{Antibacterial activity of the plant extracts}

The antibacterial activity of the crude extracts was determined by using both gram positive and gram negative bacteria. Three gram positive bacteria namely Bacillus megaterium (NCIM 2187), Lactobacillus acidophilus (MTCC 495), Enterococcus faecalis (MTCC 439) and three gram negative bacteria namely Klebsiella pneumonia (MTCC 109), Proteus vulgaris (MTCC 7299) and Escherichia coli (ATCC 35218), antifungal activity against Candida albicans (ATCC 10231) and Aspergillus flavus (ATCC 9643 )

\section{Antibacterial screening}

Antibacterial screening was determined by agar well diffusion method (Bauer et al., 1966). Suspensions of different bacteria were prepared by using 24 hours old bacterial cultures. Using these bacterial suspensions, agar plates were prepared individually by following pour plate method. After solidification, $6 \mathrm{~mm}$ diameter wells were punched in agar plate with a sterile cork borer. The plates were incubated at $37^{\circ} \mathrm{C}$ for 24 hours. After incubation, diameter of the zone of inhibition was measured. For each sample and Bacterial species, triplicates were maintained.

\section{Antifungal screening}

The fungi were grown in Czapek dox agar media at $28^{\circ} \mathrm{c}$ and spores were collected after 5-6 days from agar plates.

\section{Determination of MIC}

Minimum inhibitory concentration was determined by using broth dilution method. Minimum Inhibitory Concentrations were determined at different concentrations viz., $50 \mu \mathrm{g} / \mathrm{ml}, 100 \mu \mathrm{g} / \mathrm{ml}$, $150 \mathrm{~g} / \mu \mathrm{l}$ and $200 \mu \mathrm{g} / \mathrm{ml}$ on those bacterial strains which showed zones of inhibition against the plant crude extracts. Control tube was maintained for each concentration. The lowest concentration (highest dilution) of the extract that produced no visible bacterial growth, no turbidity in comparision with the control tubes was regarded as MIC

Human cell lines: The HeLa, cervical cancer cell line and MCF-7 Breast cancer cell lines were purchased from NCCS, Pune and the cells were maintained in DMEM medium supplemented with $10 \%$ FBS and the antibiotics penicillin/streptomycin $\left(0.5 \mathrm{~mL}^{-1}\right)$, in atmosphere of $5 \% \mathrm{CO}_{2} / 95 \%$ air at $37^{\circ} \mathrm{C}$.

\section{Preparation of Test Compound:}

For MTT assay, Each Test compounds were weighed separately and dissolved in DMSO. With media make up the final concentration to $1 \mathrm{mg} / \mathrm{ml}$ and the cells were treated with series of concentrations from 10 to $100 \mu \mathrm{g} / \mathrm{ml}$.

\section{Principle of MTT assay:}

MTT Assay is a colorimetric assay that measures the reduction of yellow 3-(4,5-dimethythiazol- 2-yl)-2,5diphenyl tetrazolium bromide (MTT) by mitochondrial succinate dehydrogenase. The assay depends both on the number of cells present and on the assumption that dead cells or their products do not reduce tetrazolium. The MTT enters the cells and passes into the mitochondria where it is reduced to an insoluble, dark purple colored formazan crystals. The cells are then solubilized with a DMSO and the released, solubilized formazan reagent is measured spectrophotometrically at $570 \mathrm{~nm}$.

\section{Procedure}

Cell viability was evaluated by the MTT Assay with three independent experiments with six concentrations of compounds in triplicates. HeLa and MCF-7cells were trypsinized and perform the Tryphan blue assay to know viable cells in cell suspension. Cells were counted by haemocytometer and seeded at density of $5.0 \times 10^{3}$ cells / well in $100 \mu \mathrm{l}$ media in 96 well plate culture medium and incubated overnight at $37^{\circ} \mathrm{C}$. After incubation, take off the old media and add fresh media $100 \mu \mathrm{l}$ with different concentrations of test compound in represented wells in 96 plates. After 48 hrs., Discard the drug solution and add the fresh medic with MTT solution $\left(0.5 \mathrm{mg} / \mathrm{mL}^{-1}\right)$ was added to each well and plates were incubated at $37^{\circ} \mathrm{C}$ for $3 \mathrm{hrs}$. At the end of incubation time, precipitates are formed as a result of the reduction of the MTT salt to chromophore formazan crystals by the cells with metabolically active mitochondria. The optical density of solubilized crystals in DMSO was measured at $570 \mathrm{~nm}$ on a microplate reader. The percentage growth inhibition was calculated using the following formula and concentration of test drug needed to inhibit cell growth by $50 \%$ values is 
generated from the dose-response curves for each cell line using with origin software.

$\%$ Inhibition $=100($ Control - Treatment $)$
Control
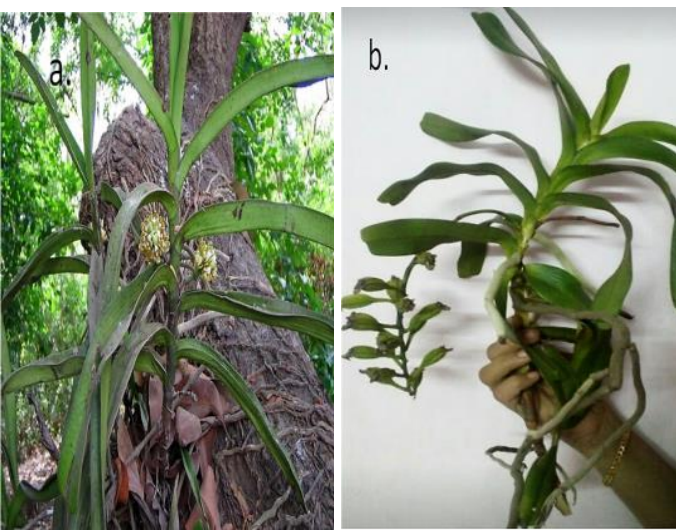

Figure 1: a. Acampe praemorsa b. Aeridis odarata
Figure 2: Highest zones of inhibition of extracts against microbes

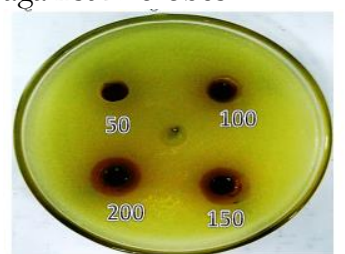

a.

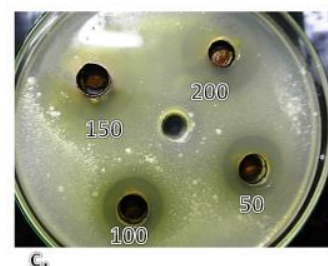

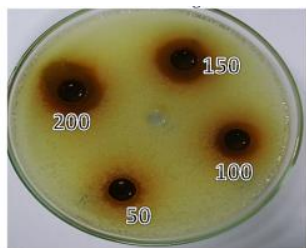

b.

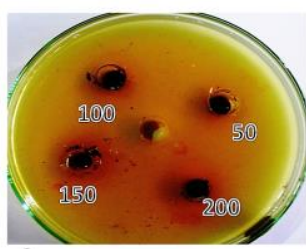

d. against Bacillus megaterium

b. Methanolic extract of Aeridis odarata against Klebsiella pneumoniae

c. Ethyl acetate extract of Aeridis odarata against Lactobacillus acidophilus

d. Ethyl acetate extract of Acampe praemorsa against Candida albican.

Table 1. Zones of inhibitions of plant extracts against microbes

\begin{tabular}{lcccc}
\hline \multicolumn{1}{c}{ Micro organism } & $\begin{array}{c}\text { Methanolic extract } \\
\text { of Acampe } \\
\text { praemorsa }\end{array}$ & $\begin{array}{c}\text { Ethyl acetate extract } \\
\text { of Acampe } \\
\text { praemorsa }\end{array}$ & $\begin{array}{c}\text { Methanolic extract } \\
\text { of Aeridis odarata }\end{array}$ & $\begin{array}{c}\text { Ethyl acetate } \\
\text { extract of Aeridis } \\
\text { odarata }\end{array}$ \\
\hline Bacillus megaterium (NCIM 2187) & 11 & 9 & 10 & 14 \\
Lactobacillus acidophilus (MTCC 495) & 8 & 14 & 9 & 17 \\
Klebsiella pneumoniae (MTCC 109) & 6 & 11 & 11 & 9 \\
Escherichia coli (ATCC 35218) & 9 & 13 & 8 & 11 \\
Enterococcus faecalis (MTCC 439) & 5 & 14 & 12 & 12 \\
Proteus vulgaris (MTCC 7299) & 7 & 7 & 10 & 10 \\
Candida albicans (ATCC 10231) & 12 & 17 & 9 & 14 \\
Aspergillus flavus (ATCC 9643) & 0 & 8 & 0 & 7 \\
\hline
\end{tabular}

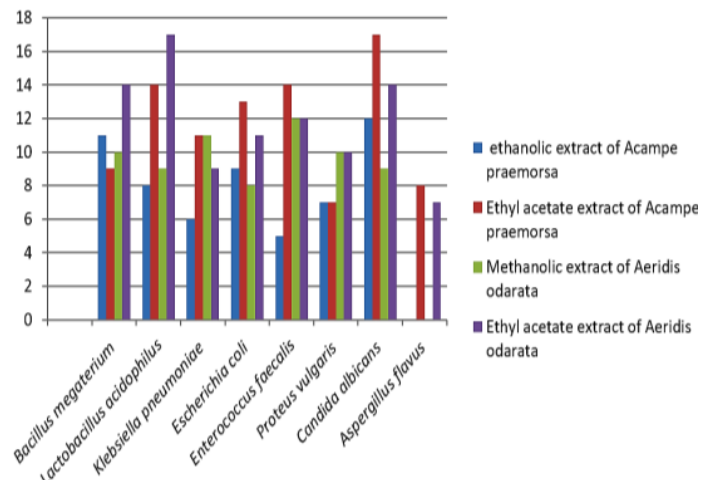

Figure 3. Zones of inhibition of plant extracts against different microbes

Antibacterial and antifungal activity of the plant leaf extracts were assessed in terms of zone of inhibition of bacterial, fungal growths, the results against test organisms shown in the table 1. Ethyl acetate extracts of the plant leaves showed considerably more activity with high zones of inhibition against all bacteria except Acampe praemorsa extract against Bacillus megaterium and Aeridis odarata extract against Klebsiella pneumoniae. Ethyl acetate and Methanolic extracts of both plants against Proteus vulgaris showed same zone of inhibition. Both extracts of Aeridis odarata showed same zone of inhibition against Enterococcus faecalis. Ethyl acetate extract of Aeridis odarata found to be more active with the inhibition zone $17 \mathrm{~mm}$ against Lactobacillus acidophilus and Ethyl acetate extract of Acampe praemorsa, with inhibition zone $17 \mathrm{~mm}$ against Candida albicans, methanolic extract of both plant leaves did not show any zone of inhibition against Aspergillus flavus.

The MIC values of extracts were determined as the lowest concentration that completely inhibited bacterial growth after 48 hours of incubation at $37^{\circ} \mathrm{c}$. Least MIC value for methanolic extract of Acampe praemorsa against all bacteria is $100 \mu \mathrm{l}$, least MIC for the extract of Aeridis odarata against Lactobacillus acidophilus, Enterococcus faecalis was observed at $50 \mu \mathrm{l}$, followed by Proteus vulgaris and Escherichia coli at $100 \mu \mathrm{l}$, Efficient MIC values were observed for ethyl acetate extract of all plant leaves,

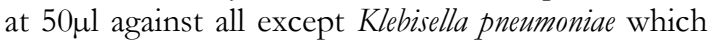
showed at $100 \mu l$. 


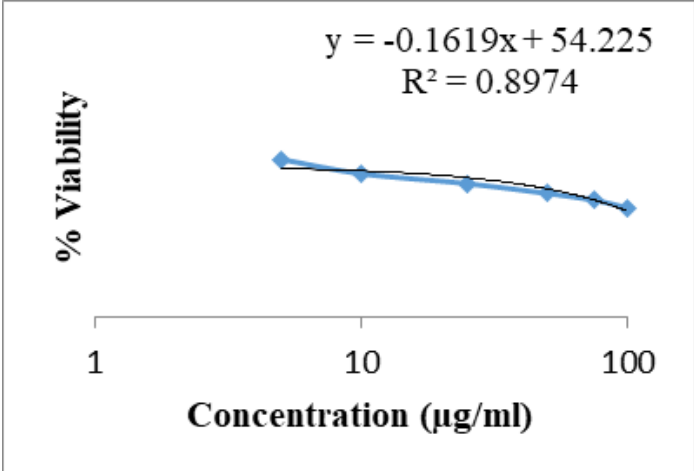

Figure 4. In-vitro cytotoxic effect of Aeridis odarata methanolic extract on MCF-7 cancer Cell Line

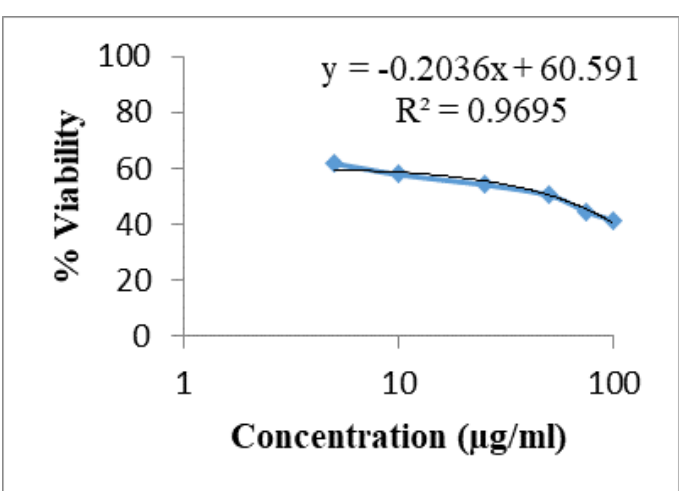

Figure 5. Cytotoxic effect of Aeridis odarata methanolic extract on HeLa Cell Line

Table 2. In Vitro Cytotoxicity

\begin{tabular}{llll}
\hline \multirow{2}{*}{ S. No } & \multicolumn{1}{c}{ Sample Name } & \multicolumn{2}{c}{ Ic50 $(\boldsymbol{\mu g} / \mathbf{M 1})$} \\
& & Hela Cells & Mcf-7 Cells \\
\hline 1 & Acampe praemorsa Methanolic extract & 76.94 & 55.90 \\
2 & Aeridis odarata methanolic extract & 52.16 & 26.21 \\
3 & Acampe praemorsa ethyl acetate extract & 61.68 & 49.27 \\
4 & Aeridis odarata ethyl acetate extract & 59.06 & 41.09 \\
5 & Cisplatin & 4.05 & 6.93 \\
\hline
\end{tabular}

Table 3. Cytotoxic Properties of on MCF -7 Cell Line

\begin{tabular}{|c|c|c|c|c|c|c|c|}
\hline Concentration(uM) & Absork & ance at & $570 \mathrm{~nm}$ & Average & Average-Blank & $\%$ Viability & $\mathrm{IC}_{50}(\mathrm{uM})$ \\
\hline 100 & 0.814 & 0.816 & 0.818 & 0.816 & 0.809 & 39.31 & \multirow{8}{*}{26.211} \\
\hline 75 & 0.871 & 0.873 & 0.875 & 0.873 & 0.866 & 42.079 & \\
\hline 50 & 0.922 & 0.924 & 0.925 & 0.923 & 0.916 & 44.509 & \\
\hline 25 & 0.995 & 0.997 & 0.998 & 0.996 & 0.989 & 48.056 & \\
\hline 10 & 1.068 & 1.07 & 1.072 & 1.07 & 1.063 & 51.652 & \\
\hline 5 & 1.176 & 1.178 & 1.179 & 1.177 & 1.17 & 56.851 & \\
\hline Untreated & 2.065 & 2.066 & 2.065 & 2.065 & 2.058 & 100 & \\
\hline Blank & 0.007 & 0.008 & 0.007 & 0.007 & 0 & & \\
\hline
\end{tabular}

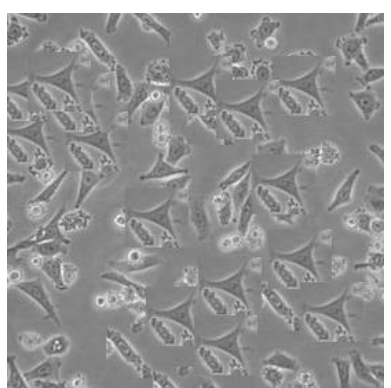

Control

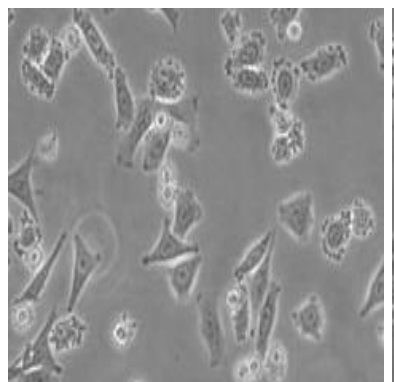

$50 \mu \mathrm{M}$

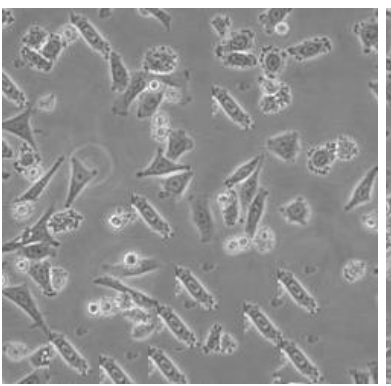

$10 \mu \mathrm{M}$

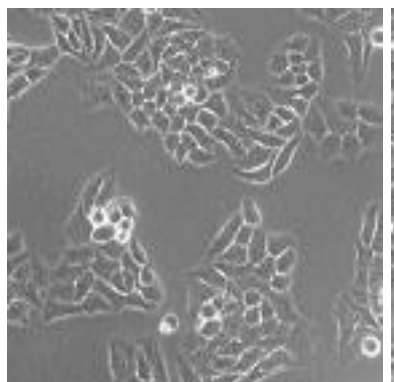

$75 \mu \mathrm{M}$

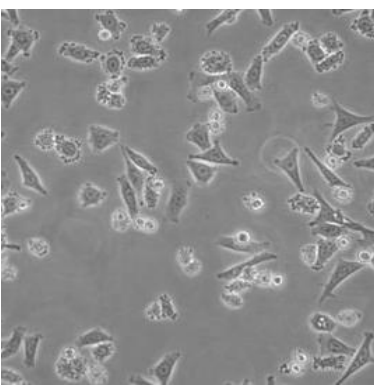

$25 \mu \mathrm{M}$

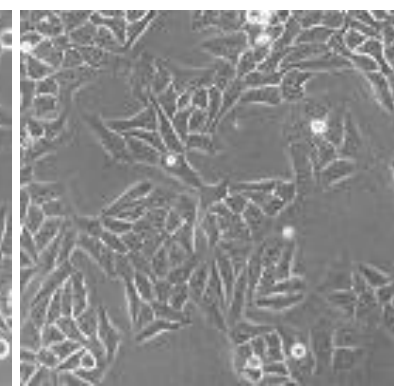

$100 \mu \mathrm{M}$

Plate 1. Anticancer activity on MCF-7 cell line in Methanolic extract of Aeridis odarata 
Table 4. In vitro cytotoxic activity of Aeridis odarata methanolic extract on HeLa Cell Line

\begin{tabular}{|c|c|c|c|c|c|c|c|}
\hline \multirow{2}{*}{$\begin{array}{l}\text { Concentration (uM) } \\
100\end{array}$} & \multicolumn{3}{|c|}{ Absorbance at $570 \mathrm{~nm}$} & \multirow{2}{*}{$\begin{array}{l}\text { Average } \\
0.793\end{array}$} & \multirow{2}{*}{$\begin{array}{l}\text { Average-Blank } \\
0.788\end{array}$} & \multirow{2}{*}{$\begin{array}{l}\text { \% Viability } \\
41.299\end{array}$} & \multirow[t]{2}{*}{ IC50 (uM } \\
\hline & 0.791 & 0.793 & 0.795 & & & & \\
\hline 75 & 0.85 & 0.852 & 0.854 & 0.852 & 0.847 & 44.392 & \multirow{7}{*}{52.167} \\
\hline 50 & 0.963 & 0.965 & 0.967 & 0.965 & 0.96 & 50.314 & \\
\hline 25 & 1.036 & 1.038 & 1.039 & 1.037 & 1.032 & 54.088 & \\
\hline 10 & 1.105 & 1.107 & 1.109 & 1.107 & 1.102 & 57.756 & \\
\hline 5 & 1.181 & 1.183 & 1.185 & 1.183 & 1.178 & 61.74 & \\
\hline Untreated & 1.913 & 1.914 & 1.913 & 1.913 & 1.908 & 100 & \\
\hline Blank & 0.005 & 0.006 & 0.005 & 0.005 & 0 & & \\
\hline
\end{tabular}
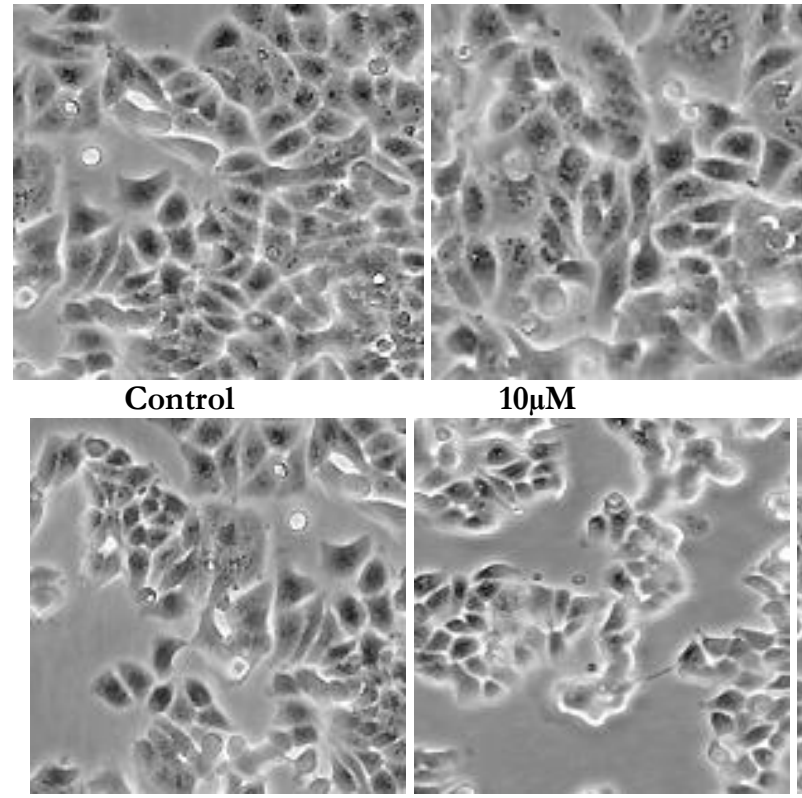

$50 \mu \mathrm{M}$
$10 \mu \mathrm{M}$

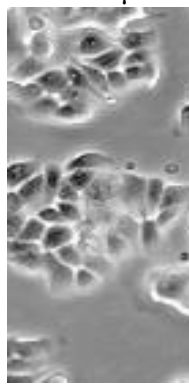

$75 \mu \mathrm{M}$

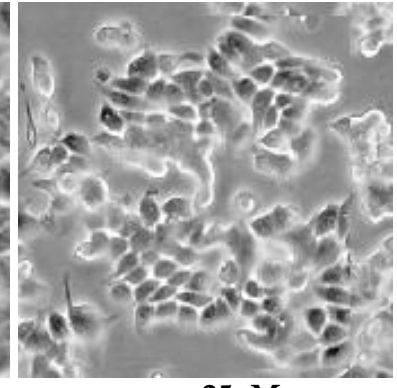

$25 \mu \mathrm{M}$

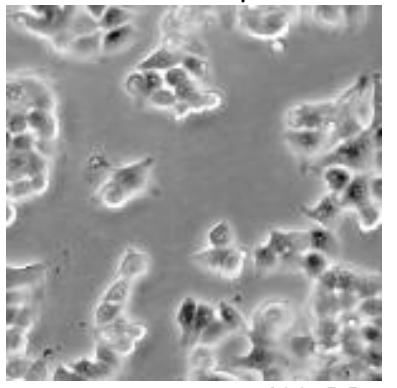

$100 \mu \mathrm{M}$

Plate 2. Anticancer activity of methanolic extract of Aeridis odarata on HeLa cell lines
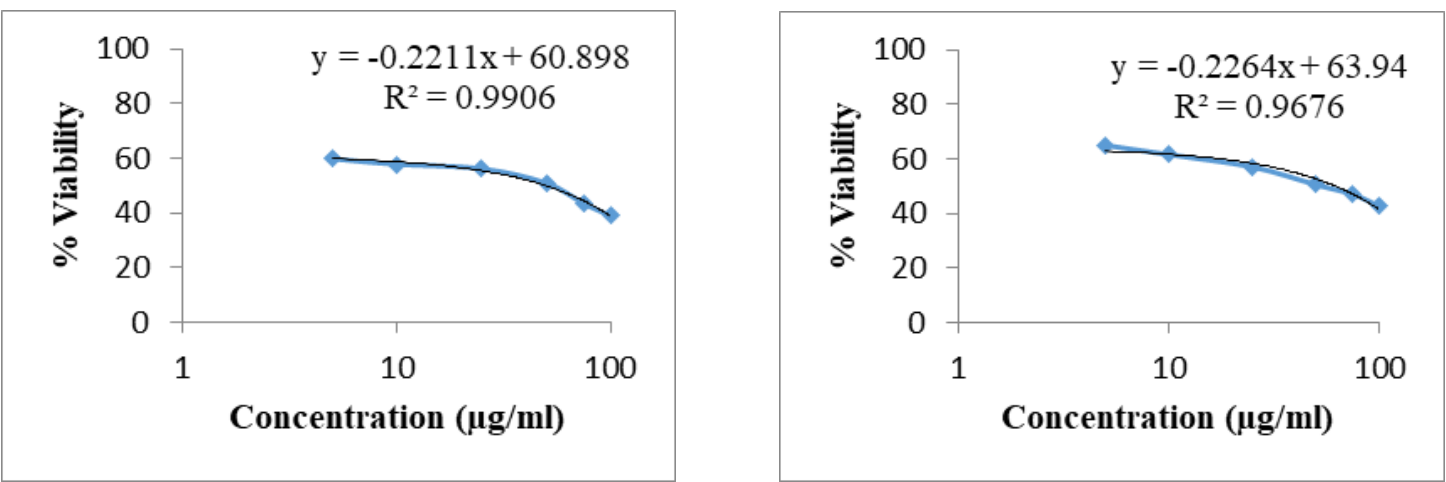

Figure 6. In-vitro cytotoxic effect of Ethyl acetate extract of Acampe praemorsa on MCF-7 Cell Lin Figure 7. Cytotoxic effect of Acampe praemorsa ethyl acetate extract on HeLa Cell Line

Table 5: In vitro cytotoxic effect of Ethyl acetate extract of Acampe praemorsa on MCF -7 Cell Line

\begin{tabular}{|c|c|c|c|c|c|c|c|}
\hline \multirow{2}{*}{$\begin{array}{l}\text { Concentration(uM) } \\
100\end{array}$} & \multicolumn{3}{|c|}{ Absorbance at $570 \mathrm{~nm}$} & \multirow{2}{*}{$\begin{array}{l}\text { Average } \\
0.807\end{array}$} & \multirow{2}{*}{$\begin{array}{l}\text { Average-Blank } \\
0.8\end{array}$} & \multirow{2}{*}{$\frac{\text { \% Viability }}{38.872}$} & \multirow[t]{2}{*}{$\mathrm{IC}_{50}(\mathrm{uM})$} \\
\hline & 0.805 & 0.807 & 0.809 & & & & \\
\hline 75 & 0.898 & 0.9 & 0.902 & 0.9 & 0.893 & 43.391 & \multirow{7}{*}{49.276} \\
\hline 50 & 1.052 & 1.054 & 1.056 & 1.054 & 1.047 & 50.874 & \\
\hline 25 & 1.161 & 1.163 & 1.164 & 1.162 & 1.155 & 56.122 & \\
\hline 10 & 1.195 & 1.197 & 1.198 & 1.196 & 1.189 & 57.774 & \\
\hline 5 & 1.235 & 1.237 & 1.239 & 1.237 & 1.23 & 59.766 & \\
\hline Untreated & 2.065 & 2.066 & 2.065 & 2.065 & 2.058 & 100 & \\
\hline Blank & 0.007 & 0.008 & 0.007 & 0.007 & 0 & & \\
\hline
\end{tabular}




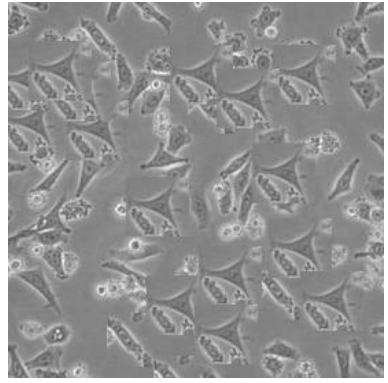

\section{Control}

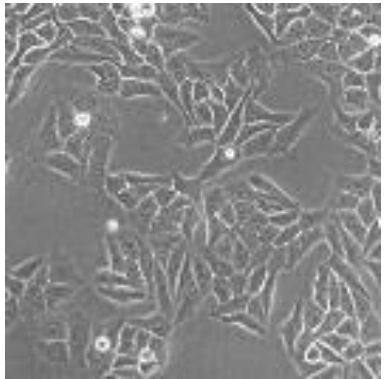

$50 \mu \mathrm{M}$

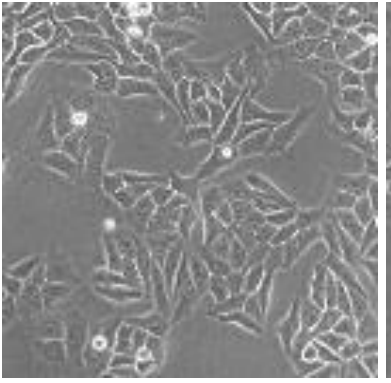

$10 \mu \mathrm{M}$

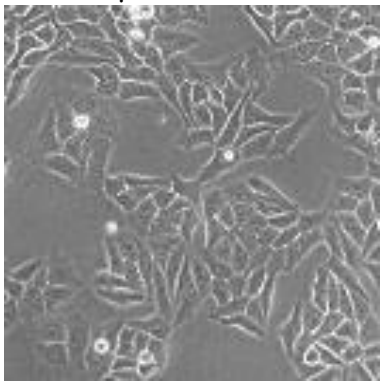

$75 \mu \mathrm{M}$

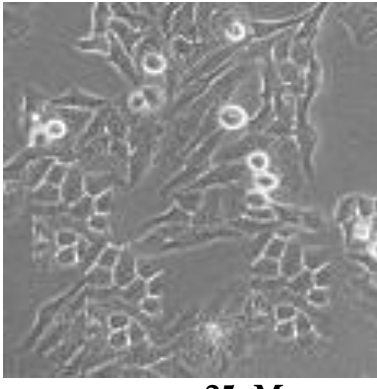

$25 \mu \mathrm{M}$

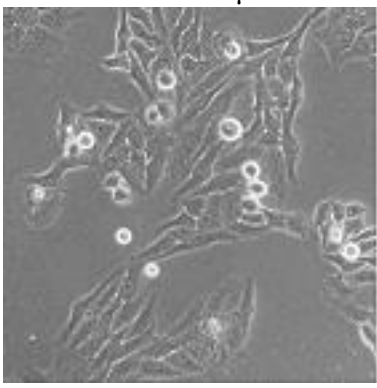

$100 \mu \mathrm{M}$

Plate 3. Anticancer activity of Ethyl acetate extract of Acampe praemorsa on MCF-7 cell line

Table 6. In vitro cytotoxic activity of Acampe praemorsa ethyl acetate extract on HeLa Cell Line

\begin{tabular}{|c|c|c|c|c|c|c|c|}
\hline Concentration(uM) & Absorl & ance $\mathbf{a}$ & $70 \mathrm{~nm}$ & Average & Average-Blank & $\%$ Viability & $\mathrm{IC}_{50}(\mathrm{uM})$ \\
\hline 100 & 0.815 & 0.817 & 0.819 & 0.817 & 0.812 & 42.557 & \multirow{8}{*}{61.681} \\
\hline 75 & 0.899 & 0.901 & 0.903 & 0.901 & 0.896 & 46.96 & \\
\hline 50 & 0.967 & 0.969 & 0.971 & 0.969 & 0.964 & 50.524 & \\
\hline 25 & 1.091 & 1.093 & 1.095 & 1.093 & 1.088 & 57.023 & \\
\hline 10 & 1.178 & 1.18 & 1.182 & 1.18 & 1.175 & 61.582 & \\
\hline 5 & 1.243 & 1.245 & 1.247 & 1.245 & 1.24 & 64.989 & \\
\hline Untreated & 1.913 & 1.914 & 1.913 & 1.913 & 1.908 & 100 & \\
\hline Blank & 0.005 & 0.006 & 0.005 & 0.005 & 0 & & \\
\hline
\end{tabular}

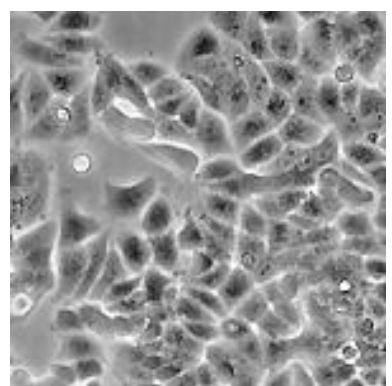

Control

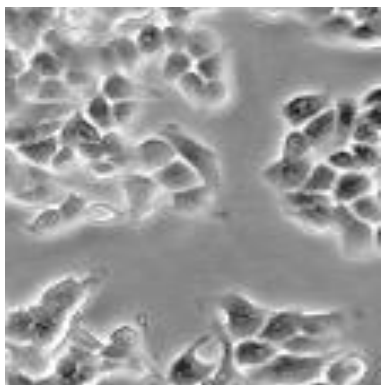

$50 \mu \mathrm{M}$

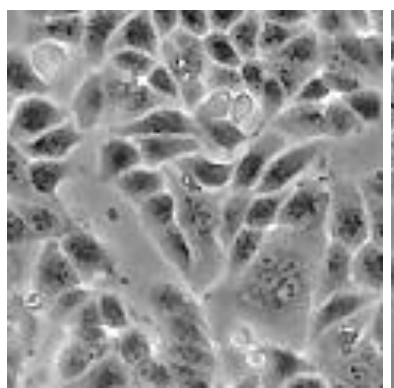

$10 \mu \mathrm{MM}$

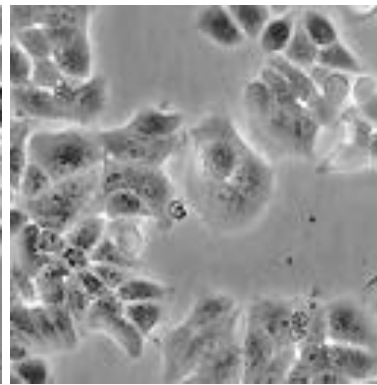

$75 \mu \mathrm{M}$

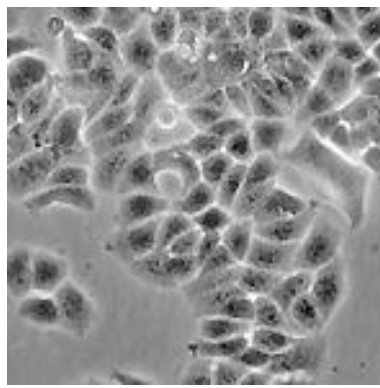

$25 \mu \mathrm{M}$

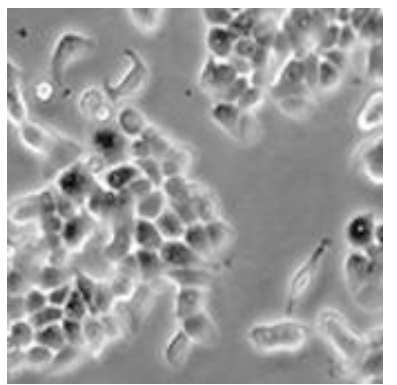

$100 \mu \mathrm{M}$

Plate 4. Anticancer activity of Ethyl acetate extract of Acampe praemorsa on HeLa cell lines

In vitro cytotoxicity of ethyl acetate extract of Acampe praemorsa (Fig 7, Plate 4) is more against HeLa cell lines and methanolic extract of Aeridis odarata (Fig 4, Plate 1) is more against MCF-7 cell lines, cytotoxicity of methanolic extract of Aeridis odarata towards MCF-7 cell line was found to 
suppress more cell proliferation, and it showed good cytotoxicity than HeLa cell line (table 2), IC $50(\mu \mathrm{g} / \mathrm{ml})$ is 26.21. The percentage growth inhibition was found to be increasing with increasing concentration of test compounds and that was showed in Fig4, Tab3, and plate1

\section{Discussions}

Experimental works have been conducted since many years in all parts of the world and various chemical compounds were isolated from these plant extracts which possess pharmacological activities. Petroleum ether extract of Acampe praemorsa leaf showed significant activity against Escherichia coli $16.66 \mathrm{~mm}$, methanolic extract showed good zone of inhibition against Klebsiella pneumonia $14.00 \mathrm{~mm}$ (Geeta Swami et al., 2014). Acampe praemorsa has been reported to contain Phenanthropyran derivative Praemorsin (1,7-dihydroxy-3-methoxy9,10-dihydrophenanthropyran) (Anuradha et al., 1994). In the studies of "Antimicrobial efficacy of orchids as potential inhibitors of antibiotic resistant strains of Escherichia coli", found that ethanolic extract of Aeridis odarata showed highest zone of inhibition $6 \mathrm{~mm}$ of Aeridis odarata extract against ampicillin resistant Escherichia coli (Paul et al., 2013) Antioxidant activity of in vitro and In vivo grown leaves of Aeridis odarata was carried out and found phenolics, flavinoids are responsible for their antioxidant activity (Prasad et al., 2016) Phytochemical analysis of Acampe praemorsa was done earlier by (Maridas et al., 2008) and found that cyanogenic glycosoides and flavinoids were present in Acampe praemorsa. Presence of alkoloids, flavinoids, terpenoids, tannins, steroids, phenols, glycosoides were also confirmed in the studies of (Mari Suji \& Christudas, 2008)

Aeridis odarata exhibits inhibitory activity against antibiotic-sensitive, pencillin-resistant and kanamycin-resistant strains of Escherichia coli, common organisms in stools, on skin and in superficial infections (Springer). Antibiotic properties of Aeridis odarata were also mentioned (Arditti, 1984)An oral Indian preparation for treating painful, swollen joints contains four herbal products, one of which is Aeridis odarata (Dash et al., 2008). This plant is valued by the tribal people of South-East Bangladesh for medicinal purposes mainly as anti-inflammatory and anti-cancer agents. Aeridis odarata fractions showed remarkable inhibiton in NFLB test, selected for further investigation, the HPCL was performed to isolate the pure compound, antioxidant activity was performed along with antioxidant activity (Mohammed Kamrul Huda). Considering its medicinal purpose mainly as anticancer agent, this was sequenced with barcode gene, matK, which is now available in the national centre for Biotechnological information gene bank (29). In our MTT assay also methanolic extract of Aeridis odarata against MCF-7 cell lines has less IC 50 value, showing the anticancer property.

\section{Conclusion}

These plants possess good antimicrobial activity and methanolic extract of Aeridis odarata against MCF-7 cell lines reveals that the plant has good anticancer activity, further analysis like fluorescent staining assay, DNA fragmentation assay could be carried out and investigation is needed to isolate the bioactive compounds in these plants to treat cancer, conservation of orchids should be done for future studies.

\section{References}

1. Acharya, D and K. Srivatsava, "Indigenous Herbal medicines; tribal formulations and traditional herbal practices" Aavishkar publishers distributor, Jaipur, India. (2008)

2. Akhtar, M., M. M. Hoque, M. Rahman, and M. K. Hossain, M. K. "Ethnobotanical investigation of some orchids used by five communities of Cox's bazaar and Chittagang hilly tracts districts of Bangladesh.” Journal of medicinal plant studies; 5.3 (2017): 265-268.

3. Anuradha, V. and N. S. R. Prakash. "Praemorsin a new phenanthropyran from Acampe praemorsa." phytochem, 37(1994): 909-910.

4. Arditti, J. and R. Ernst. "Physiology of germinating orchid seeds. In: Orchid Biology Reviews and Perspectives III. (Ed., Arditti, J.) Cornell University Press, Ithaca and London. (1984): 172-222.

5. Bauer, A. N., W. M. M., Kirby, J. C. Sherris, and M. Turek. "Antibiotic susceptibility testing by a standerdised single disc method." American journal of clinical pathology. 45 (1966): 493-496.

6. Behera, D., C. C. Rath, K. Tayung, and U. B. Mohapatra. "Ethnomedicinal uses and antibacterial activity of two orchid species collected from Simlipal Biosphere Reserve, Odisha, India. Journal of Agricultural Technology. 9.5 (2013): 1269-1283.

7. Behera. D., C. C. Rath., Umaballava, Mohapatra. "Medicinal orchids in India and their conservation: A Review". Floriculture and ornamental biotechnology. 7.1 (2013): 53-59.

8. Bijaya Pant. "Medicinal orchids and their uses: Tissue culture a potential alternative for conservation." African Journal of plant sciences. 7. 10 (2013): 448-467.

9. Bulpitt, C. J. "The uses and misuses of orchids in medicine." An International Journal of Medicine, 98 (2005): 625-631.

10. Dash, P. K., S. Sahoo, and S. Bal. "Ethnobotanical studies on orchids of Niyamgiri Hill ranges, Orissa, India”. Ethnobotanical leaflets, 12 (2008): 70-78. 
11. De, L.C. and R. P. Medhi. "Orchid- A diversified component of farming systems for profitability and livelihood security of small and marginal farmers." Journal of Global Biosciences 4 (2015): 1393-1406.

12. Geeta Swami, Salvi Jyotsna, and S. S. Katewa. "Investigating antimicrobial aspects of Acampe praemorsa (Roxb.) Blatt. \& mc." Asian Journal of Traditional Medicines, 9. 4 (2014)

13. Ho, C. K., C. C. Chen. "Moscalitin from the orchid Dendrobium loddigessi is a potential anticancer agent." Cancer Investigation. 21 (2003): 729-736.

14. Hossain., M. M. "Traditional therapeutic uses of some orchids of Bangladesh." Medicinal and Aromatic plant sciences and Biochemistry 3. 1 (2009): 100-106.

15. Kong, J. M., N. K. Goh, L. S. Chia, and T. F. Chia. "Recent advances in traditional plant drugs and orchids." Acte Pharmacolorica Sinica 24 (2003): 7-21

16. Kumar, C. S and K. S. Manilal. "A catalogue of Indian orchids, Bishan Singh Mahendra pal Singh, Dehradun, India”. (1994)

17. Maridas, M, M. I. Zahir Hussain, M. I, and G. Raju "Phytochemical survey of Orchids in the Tiruelveli Hills of South India." Ethnobotanical leaflets 12 (2008): 705-12.

18. Mary Suji, $\mathrm{R}$ and Christudas Willians "Micropropagation, Phytochemical studies and Antioxidant potential of a wild epiphyte orchid. Acampe praemorsa (Roxb.) of Kanyakumari district, India." European Journal of Pharmaceutical and Medical research, 3.5 (2016): 572-576

19. Mohammed Kamrul Huda "Phytochemistry and Barcoding of Medicinally Important Orchids of Bangladesh." Post-doctoral research fellow, Department of Plant and soil science, University of Aberdeen, Aberdeen, AB 24 3UU, UK

20. Mohammed Kamrul Huda "Conservation of two medicinal orchids in Bangladesh", Professor and chairman, Department of Botany, University of Chittagong, Chittgong, Bangladesh.

21. Mohanty, J. P., P. Pal, and B. A. Das. "An overview on orchids." Universal Journal of Pharmaceutical Sciences and research. 1. 1 (2015): 49-50.

22. Padal, S. B., B. Sandhyasri, and P. Chandrasekhar. "Tradfitional uses of Monocotyledon Plants of
Aruku valley Mandalam, Visakhapatnam District, Andhra Pradesh, India." IOSR Journal of Pharmacy and Biological Sciences. 6. 2 (2013): 12-16.

23. Pankaj Oudhia. "Medicinal orchid Aeridis odarata Lour, based herbal formulations used for skin diseases." Indian Traditional Healing: Ethnobotanical surveys (1990-2012)

24. Pant \& B. B. Raskoti. "Medicinal orchids of Nepal, Kathmandu, Himalayan Map house (p) ltd. (2013)

25. Paul, P., A. Choudary, D. Nath, and M. K. Bhattacharjee. "Antimicrobial efficacy of orchid extracts as potential extracts of antibiotic resistant strains of E. coli." African journal of Pharmaceutical clinic, Res. 6.3 (2013): 108-111.

26. Prasad, G., A. A. Mao, D. Vijayan, S. Mandal, K. Chaudhuri, and T. Seal. "Comparitive HPLC finger printing and antioxidant activities of in vitro and in vivo grown Aeridis odarata, A medicinal orchid", Journal of Chemical, Biological and Physical sciences. 6. 2 (2016): 454-468.

27. Reddy, K. N., G.V. Subba raju, Ch. Sudhakar reddy, and V. S. Raju. "Ethnobotany of certain orchids of Eastern Ghats of Andhra Pradesh.” 2. 3 (2005)

28. Shanavaskhan, A. E., M. Sivadasan, A. H. Alfarhan, and Jacob Thomas. "Ethnomedicinal aspects of angiospermic epiphytes and parasites of Kerala, India". Indian Journal of Traditional Knowledge. 11 2 (2012): 250-258.

29. Springer "Acampe to Arundina"

30. Westh, H., C. S. Zinn, V. T. Rostahl, Sarisa study group: An international consumption and resistance in Staphylococus aureus from 15 hospitals in 14 countries Microbial dry resistance 10 (2004): 169176.

31. White, K. J and B. Sharma. "Wild orchids in Nepal": The guide to the Himalaya orchids of the Tribhuvan Rajpath and Chitwan Jungle: Bangkok Thailand. (2000). White Lotus Press.

\section{Cite this article as:}

Jhansi K., Khasim S.M. Antimicrobial and in vitro cytotoxic studies of Acampe praemorsa and Aeridis odarata of Orchidaceae. Annals of Plant Sciences 7.2 (2018) pp. 2088-2095.

do $\mathrm{http}: / /$ dx.doi.org/10.21746/aps.2018.7.2.19 